\title{
Budget impact analysis of the simplification to atazanavir + ritonavir + lamivudine dual therapy of HIV-positive patients receiving atazanavir- based triple therapies in Italy starting from data of the Atlas-M trial [Corrigendum]
}

\author{
Restelli U, Fabbiani M, Di Giambenedetto S, Nappi C, \\ Croce D. Clinicoecon Outcomes Res. 2017;9:173-179.
}

On page 174, Methods section, $1^{\text {st }}$ paragraph, the last sentence reads "The percentage of patients eligible for dual therapy $(\mathrm{ATV}+\mathrm{r}+3 \mathrm{TC})$ was derived from the Atlas-M trial at 48 weeks, ${ }^{20}$ in which patients were eligible to simplification if aged $>17$ years, receiving for at least 6 months ATV $+r+2$ NRTI, with "at least two HIV-RNA levels $<50$ copies/mL on two consecutive determinations at least 3 months apart," for at least 6 months with a CD 4 cell count $>200$ cells $/ \mathrm{mm}^{3}$, no history of AIDS-related events in the year before enrollment.". The correct sentence is "The percentage of patients eligible for dual therapy (ATV $+\mathrm{r}+3 \mathrm{TC})$ was derived from the Atlas-M trial at 48 weeks, ${ }^{20}$ in which patients were eligible to simplification if aged $\geq 18$ years, receiving for at least 6 months ATV+r+2 NRTI, with "at least two HIV-RNA levels $<50$ copies $/ \mathrm{mL}$ on two consecutive determinations at least 3 months apart," for at least 6 months with a CD4 cell count $>200$ cells $/ \mathrm{mm}^{3}$, no history of AIDS-related events in the year before enrollment.".

\section{Publish your work in this journal}

ClinicoEconomics and Outcomes Research is an international, peerreviewed open-access journal focusing on health technology assessment, pharmacoeconomics and outcomes research in the areas of diagnosis, medical devices, and clinical, surgical and pharmacological intervention. The economic impact of health policy and health systems organization also constitute important areas of coverage. The manuscript management system is completely online and includes a very quick and fair peer-review system, which is all easy to use. Visit http://www.dovepress.com/testimonials.php to read real quotes from published authors. 